\title{
GLOBAALEJA NÄKÖKULMIA KOULUTUKSEEN
}

Bhola S., World trends and issues in adult education. Unesco: Guildford. 1988. 177 s.

Takala T., Kehitysmaiden koulutusongelmia. Gaudeamus: Helsinki. 1989. 207 s.

Hakovirta H., Pakolaisuus. Kustannus 54: Tampere. 1989. $135 \mathrm{~s}$.

Indianan yliopiston professori H. S. Bholan kirjoittama teos käsittelee laajasti aikuiskasvatuksen kehityssuuntia eri maissa. Takakansi kertoo kirjan kohdistetun niin politiikan tekijöille kuin tutkijoille ja käytännön aikuiskasvattajille muiden muassa.

Teoksen yhtenä tavoitteena on ollut kuvata monipuolisesti aikuiskasvatuksen neljän viime vuosikymmenen kehitystä, Helsingin kokouksesta vuodesta 1949 alkaen. Teoksen rakenteen logiikka perustuu etenemisjärjestykseen, jossa teoreettisten kysymysten - aikuiskasvatuksen käsite, filosofiset ja ideologiset perusteet, teoria ja tutkimus - käsittely edeltää aikuiskasvatuskäytännön eri puolten tarkastelua.

Bhola noudattaa useimmissa teoksensa pääluvuissa samaa aiheen käsittelytapaa. Keskeisten asioiden tarkastelussa on mukana katsaus aikuiskasvatuksen maailmankonferensseissa (Helsingør, 1949; Montreal 1960; Tokio 1972 ja Pariisi 1985) ko. asiasta sanottuun. Yhtenäisyyttä käsittelyyn luo myös läpi teoksen suoritettu vertailu markkinatalousmaiden, keskusjohtoisten maiden (suunnitelmatalousmaiden) ja kolmannen maailman kesken.

Vertailevan kasvatustieteen näkökulmasta ahtaasti arvioituna vertailu ei täytä kaikkia tieteellisyyden kriteereitä. Liian usein jäädään tilanteen kuvailun asteelle. Lisäksi vertailtavien blokkien sisällä eri "'muuttujia" tarkastellessa ei ole riittävästi pitäydytty yhtenäisessä aineistossa.

Kolmanneksi voidaan todeta, että eurooppalaisin silmin vertailu näyttää joiltakin osin su- pistuneen tarpeettoman painotetusti kolmannen maailman aikuiskasvatuksen ilmiöiden tarkasteluksi.

Kirjan antoisimpana osuutena voi pitää sen aikuiskasvatuksen teoreettisiin kysymyksiin painottuvia jaksoja. Käytännön aikuiskasvatuksen kuvaus jää monilta osin vaillinaiseksi eikä näin ylletä esimerkiksi kolmannen maailman osalta siihen, mitä joskus aikaisemmin on asiasta kirjoitettu 1).

Bholan teos on varsin merkittävä lisä aikuiskasvatusta globaalissa perspektiivissä tarkastelemaan pyrkivien, toistaiseksi vähälukuisten teosten joukkoon. Erityisesti kirjan lähihistorian kehitykseen, teoreettisten kysymysten pohdiskeluun ja kolmannen maailman aikuiskasvatuksen olemukseen kohdistuvat osat antavat uusia näkökulmia myös aikuiskasvatuskirjallisuuteen jo laajemminkin perehtyneille.

Tuomas Takalan, kehitysmaiden koulutusongelmia käsittelevä teos on merkittävä suomenkielinen uutuus alan kirjallisuudessa. Teoksessa ei vain kuvailla kehitysmaiden koulutusoloja, vaan otsikon mukaisesti paneudutaan analyyttisesti myös koulutuksen ongelmiin. Teoksensa johdanto-osassa Takala korostaa monien ongelmien olevan yhteisiä kaikille kehitysmaille. Toisaalta löytyy selviäkin eroja, jotka liittyvät poliittisiin järjestelmiin tai kulttuurien erilaisuuteen. Yhtenä esimerkkialueena kulttuuritaustaisista eroista Takala mainitsee voimakkaasti erilaisen suhtautumisen tyttöjen ja naisten kouluttamiseen. 
Takalan empiirinen aineisto koostuu pääasiallisesti erilaisista kansainvälisistä koulutustilastoista, joiden luotettavuuteen hän suhtautuu selkeän varauksellisesti. Ongelma on tyypillinen vertailevan kasvatustieteen alueella käytettäessä tilastoja ja muita dokumenttiaineistoja tutkimusmateriaalina. Tilastojen yleisen luotettavuuden lisäksi Takala pohdiskelee eri maiden tilastojen vertailukelpoisuutta. Tilastoaineiston käytössä analyyseissään kirjoittaja on läpi teoksen kriittisen erittelevä.

Takalan teos jakautuu historiaa ja nykytilannetta sekä tulevaisuuden näkymiä ja vaihtoehtoja käsitteleviin osiin. Historiaa ja nykytilannetta tarkastellaan niin perusasteen, keski- ja korkea-asteen kuin ei-formaalin aikuiskoulutuksen osalta. Lisäksi puututaan naisten koulutuksen erityisongelmiin. Tulevaisuuden näkymät ja vaihtoehdot liitetään koulutuksen määrälliseen kehitykseen ja sen rahoitukseen, koulutuksen laatuun ja kehitysyhteistyön suuntakysymyksiin.

Aikuiskasvatuksen kannalta kirjan ehdottomasti kiinnostavin osuus on ei-formaalia aikuiskoulutusta käsittelevä jakso. Ei-formaalilla aikuiskoulutuksella Takala tarkoittaa
"sellaista koulutusta, joka on tarkoitettu perusasteen koulua käymättömille tai sen keskeyttäneille aikuisille... koulutus on yleensä ei-formaalista (non-formal educati- on) - toisin sanoen sitä ei ole jaettu luok- katasoiksi... ja opetusaikojen järjestely se- kä opetussuunnitelmat ovat suhteellisen joustavia verrattuna formaalisen koulutus- järjestelmän perusasteeseen."

(s. 42). Valittua tulkintaa ei-muodollisen aikuiskasvatuksen käsitteestä voi pitää pätevänä laajemmassakin käsitteistökehyksessä.

Ei-formaalin aikuiskoulutuksen perustehtävien - kuten luku- ja kirjoitustaito - tarkastelu on perusteellista ja valaisevaa, vaikkakin varsinainen vertailu jää niukaksi. Julkaisun oppikirjaluonne huomioonottaen se on kuitenkin riittävää.

Ei-formaalin aikuiskoulutuksen rajoituksia pohtiessaan Takala tuo esiin ainakin minulle entuudestaan osin tuntemattomia ongelmia, joiden totuudellisuuden takeena on kirjoittajan paneutuminen ongelmien taustojen ja syiden erittelyyn. Ei-formaalin aikuiskoulutuksen ongelmat näyttävät syntyvän niin toiminnan puutteellisista puitteista kuin myös aikuisten asenteista. Jälkimmäinen ilmenee selvästi kehi- aikuiskoulutuksen arvostamisena. Sen taustalla taas on laajempi yhteiskunnan toimintamekanismeihin sisältyvä käsitys etilaisen koulutuksen tuottamista todellisista ja muodollisista pätevyyksistä, joiden erilainen välinearvo on kirkastunut myös aikuisopiskelijoille.

Ei-formaalin aikuiskoulutuksen ongelmista teoksessa todetaan yhteenvetona muun muassa;

\begin{abstract}
"Ei-formaalin koulutuksen laajentamispyrkimyksiä on arvosteltu tästä näkökulmasta väittämällä, että niiden tavoitteena tai ainakin piilevänä seurauksena on kehitysmaiden väestön jakaminen kahteen ryhmään: formaalisen koulutusjärjestelmän piirissä on hyväosaisten ryhmä, jolla on mahdollisuudet edetä ylemmille koulutustasoille ja menestyä työmarkkinakilpailussa, kun taas huonompiosainen väestö saa ei-formaalia koulutusta, josta ei ole sosiaalisen nousun mabdollisuuksia." (ss. 58-59). 2).
\end{abstract}

Kehitysmaiden koulutuksen tulevaisuudennäkymistä Takala kirjoittaa varsin yllättävästi suhteessa siihen, mitä parin viime vuosikymmenen aikana on yleisesti koulutuspolitiikasta ja koulutuksen tulevaisuudesta kansainvälisillä foorumeilla puhuttu ja mistä esimerkiksi kehitysyhteistyön puitteissa tapahtunut koulutus on luonut ideologiansa.

'Jos kehitysmaiden viimeaikaista koulutuspolitiikkaa ja niiden tulevaisuudennäkymiä verrataan Ivan Illichin (1972) esittämään 'kouluttoman ybteiskunnan' ideaan tai UNESCOn asettaman komission raportissa 'Learning to be' (Opiskelu..., 1972) habmoteltuibin uusiin koulutuksen muotoibin, voidaan sanoa, että nämä sinänsä byvät ajatukset olivat ja ovat edelleen todella utopistisia."

(ss. 148-9). Esimerkiksi tämä esitetty arvio poikkeaa niistä kehitysmaiden koulutuksen kehittämistä koskevista näkemyksistä, joita esittävät usein yhtä hyvin kehitysmaiden koulutuspoliitikot ja muut suunnannäyttäjät kuin kehittyneempien maiden asiantuntijat hyviä neuvoja jakaessaan. Itse tulkitsen kehitysmaiden koulutuksen tilan Takalan esittämän kaltaiseksi.

Takalan kirja tuntuu kokonaisuutena luotettavalta ja tarkastelutavaltaan asiallisen kriittiseltä. Vertailevan kasvatustieteen metodinen ote ei ole sellainen kuin sen voisi kuvitella olevan, jos sama asia esitettäisiin tieteellisestä tutkimusraportissa. Nyt oppikirjamuodossa tarjottu 
tieto perustuu joka tapauksessa parhaimpiin mahdollisiin aineistoihin. Lukijalle avautuu taatusti uusi näkökulma kehitysmaiden koulutusoloihin ja -ongelmiin. Kirja panee ajattelemaan. Jo siksi se on lukemisen arvoinen.

Tampereen yliopiston kansainvälisen politiikan apulaisprofessori Harto Hakovirta kirjoittaa pakolaisuudesta, maailman ja meidän ongelmastamme, joka yksi tämän päivän ja näyttää olevan myös huomispäivän vakavimmista globaaleista huolenaiheista.

Kasvatukseen ja koulutukseen pakolaisuuden suhde on monitasoinen: tiedostamisen ja tiedon asia ulkopuolisille, koulutuksen järjestämisen asia pakolaisia vastaanottaville ja kysymys itsensä kehittämismahdollisuuksista pakolaisille. Pakolaisongelman keskeisenä kysymyksenä voidaan pitää sen ratkaisumahdollisuuksien ja -keinojen etsimistä ja kehittämistä. Vastausta tähän kysymykseen etsittäessä voidaan pohtia myös koulutuksen mahdollisuuksia ja keinoja vaikuttaa myönteisiin ratkaisuihin.

Hakovirta ei juurikaan tarkastele koulutuksen ja pakolaisongelman suhdetta, vaikkakin viittaa koulutuksen merkitykseen yhtenä osaongelmien hoitokeinona.

"Vielä silloin kun mahdollisesti kyseeseen tulevat, pidemmälle menevät avustustoimet, kuten vakinaisten asuntojen, koulutuksen ja luonnollisten toimeentulomahdollisuuksien järjestäminen nousee etualalle, ensiavun tyyppinen toiminta usein jatkuu toissijaisena" (s. 100).

Hakovirran teos sisältää sellaista faktatietoa, jonka soisi leviävän laajemmallekin, vaikkapa suomalaisen käytännön aikuiskasvatustyön välityksellä. Teoksessa pohditaan myös pakolaisongelman hallinta- ja ratkaisukeinoja.

Tilannekuva jää kuitenkin lohduttomaksi. Kriisit, sodat, nälkä ja taloudellinen ahdinko näyttävät lisäävän paineita pakolaisuuteen. Toi- saalta sivistyneen maailman alttius vastaanottaa hätää pakenevia ihmisiä näyttää ongelman kasvaessa vähenevän. Hakovirran teos antaa vastauksen moneen pakolaisuuden olemusta ja taustaa koskevaan kysymykseen. Lisää tietoa jakavat päivittäin joukkotiedotusvälineet. Kuinka haasteeseen vastaa esimerkiksi kansallinen kasvatussysteemimme? Varmaa on, että tarvitsemme pakolaisuudesta tosiasioita kertovaa valistusta. Siellä, missä pakolaisia vastaanotetaan joudutaan ennen pitkää pohtimaan myös koulutuksen järjestämistä.

Kasvatuksen ja koulutuksen kansainvälisessä tarkastelussa etenkin kolmannen maailman koulutuksen ilmiöiden ja niiden taustojen ymmärtäminen on monesti eurooppalaiselle vaikeaa. Luotettava tieto, jota kaikki edellä esitellyt teokset edustavat, helpottaa asiain ymmärtämistä. Tähän liittyen en malta olla lopettamatta katsaustani siteeraukseen eräältä saksalaisen aikuiskasvatuksen voimahahmolta. Professori Horst Siebert on kirjoittanut:

"Kolmas maailma -pedagogiikka kohdistuu meibin itseemme. Opimme kolmannesta maailmasta ja kolmannelta maailmalta päämääränä oma kehityksemme. Siksi meidän on ensiksi tultava tietoisiksi omasta bistoriallisesta kehityksestämme, maailmankatsomuksestamme ja mentaliteetistämme. Ulkoeurooppalaisia kansoja koskevia kantojamme leimaa eurosentrismi... 3).

\section{Viitteet}

1) Ks. esim. Coles E., Adult Education in Developing Countries. Pergamon Press: Exeter. 1969.

2) Takala viittaa tässä artikkeliin: Bock J., The institutionalization of nonformal education. Comparative Education Review, Vol. 20, no 3, 1976, 346-367.

3) Ks. Jakob M. - Siebert H., Das NordSüd-Thema in der Erwachsenenbildung. Schriftenreihe "'Lernbereich Dritte Welt". Universität Hannover, 1990, 14.

EERO PANTZAR 